\title{
Diagnosis of exercise-induced anaphylaxis: current insights [Corrigendum]
}

Pravettoni V, Incorvaia C. J Asthma Allergy. 2016;7:191-198.

On page 191, Abstract section, line 15, the word "assumption" should have read "consumption".

On page 191, Abstract section, line 19, the word "assumption" should have read "consumption".

On page 194, Table 2, the word "assumption" should have read "consumption".

On page 195, In vivo testing section, line 9, the word "assumption" should have read "consumption".

The Journal of Asthma and Allergy is an international, peer-reviewed open access journal publishing original research, reports, editorials and commentaries on the following topics: Asthma; Pulmonary physiology; Asthma related clinical health; Clinical immunology and the immunological basis of disease; Pharmacological interventions and new therapies. This journal is included in PubMed. The manuscript management system is completely online and includes a very quick and fair peer-review system, which is all easy to use. Visit http://www. dovepress.com/testimonials.php to read real quotes from published authors. 